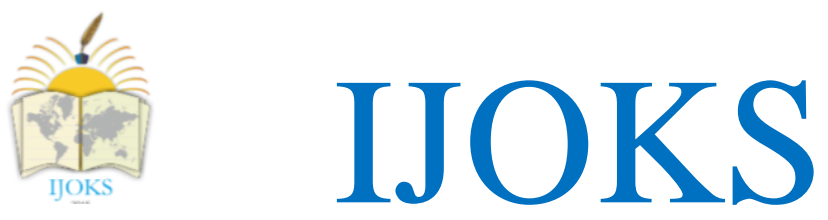

International Journal of Kurdish Studies

(ISSN:2149-2751)

3 (1), pp. $31-42$

http://www.ijoks.com

\title{
Language planning and security of the national Language
}

\section{Omed Barzan Brzoo ${ }^{1}$}

Received: Nov 03, 2016 Reviewed: Nov 16, 2016 Accepted: Nov 30, 2016

\begin{abstract}
This research is entitled "Language plan and security of the national Language".It talks about the function and political role of language planning in maintaining national language security in the face of the conflicts and threats from other languages.

The research comprises two parts:

The first part talks about kurdish language and national language security in which attention has been given to the steps that the frequent regimes in Iraq have taken towards weakening and destroying the bases and authenticity of kurdish language. The second part has been devoted to the language policy and plan for the purpose of safeguarding national language security. In addition, the relation between language and identity as well as language policy and plan and their fundamental elements have been discussed.

Further, the effect of Arabic and English languages on the syntactic structures of Kurdish has been discussed.

At the end, the most important conclusions are put forward with a list of the references.
\end{abstract}

Keywords: Language planing, National Language, Identity, Genocide.

\section{Recommended citation:}

Brzoo, O. B. (2017). Language planning and security of the national Language. International Journal of Kurdish Studies 3 (1), 31 - 42 DOI: 10.21600/ijoks.288960

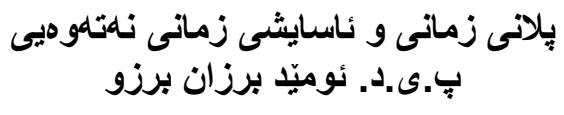

${ }^{1}$ Assistant professor Dr., Department of Kurdish Language, College of Education, Germian University, Sulaimani, Kurdistan Region - Iraq. E.mail: dr.omedbarzan@yahoo.com. 
سنورى نويَزْينهوهكه له ئاستى سينتاكسدايه به كهرمستهى فريّزو رستهى زمانى كوردى به كاريخهريى زمانهكانى عهرمبىو

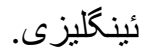

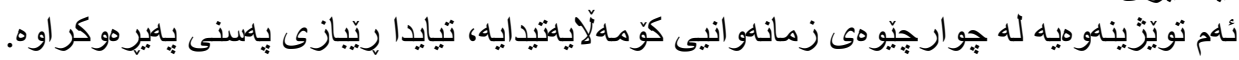

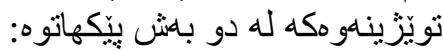

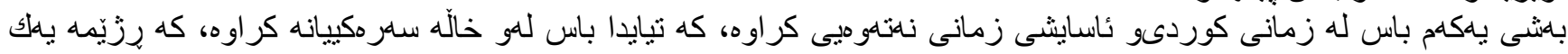

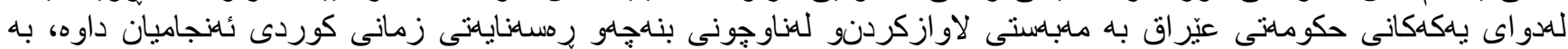

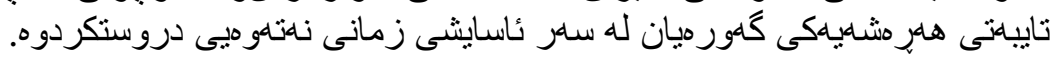

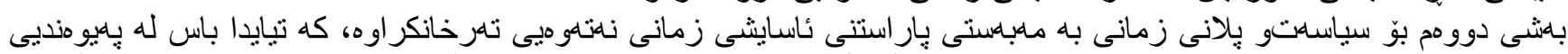





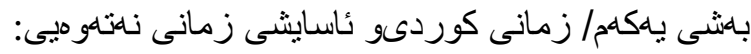

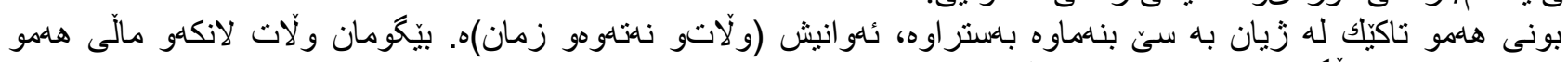

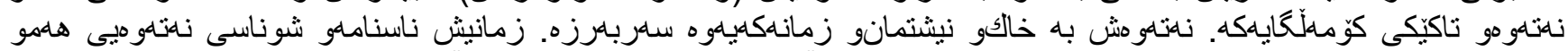

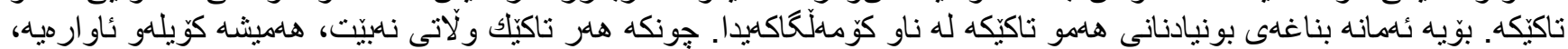

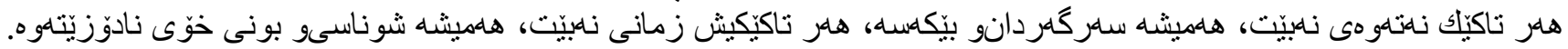

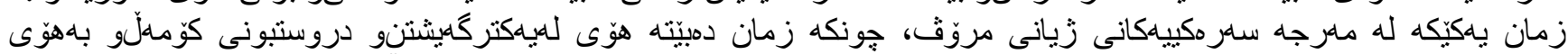

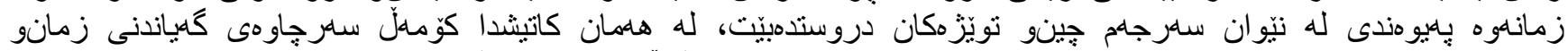

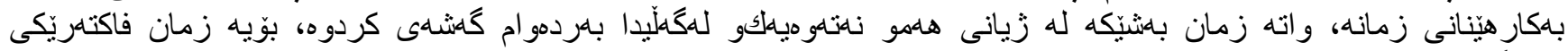

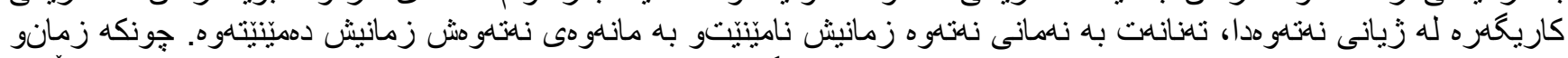

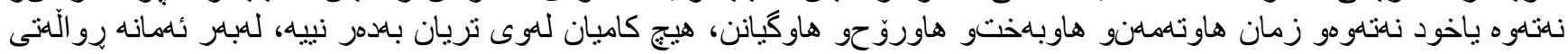



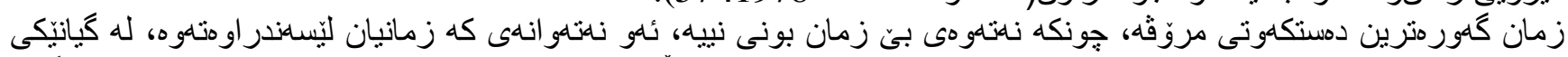

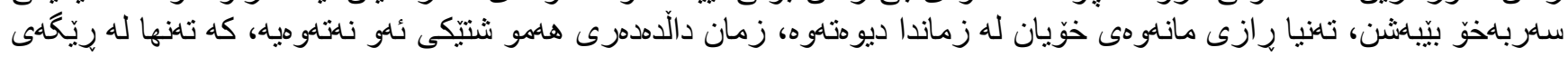

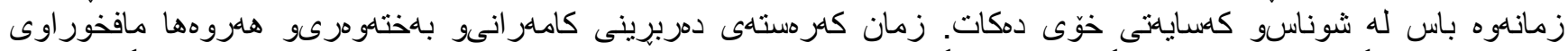

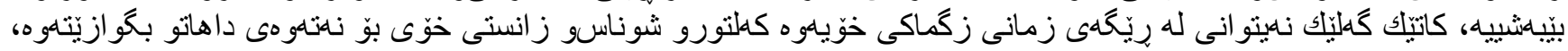

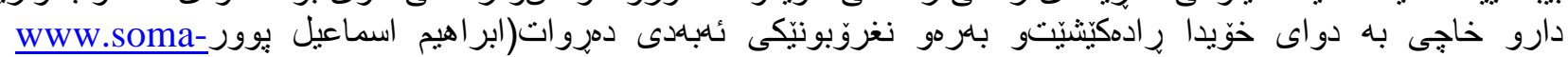

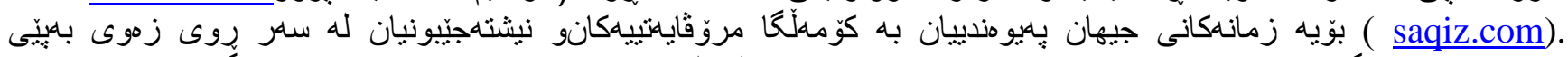

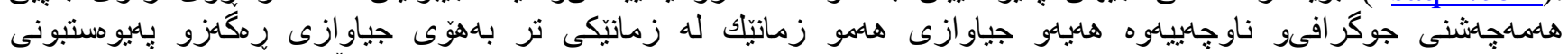

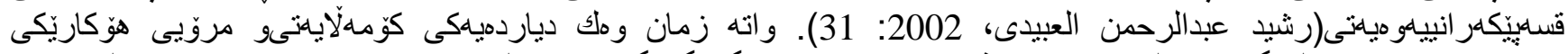

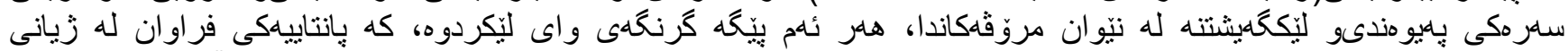



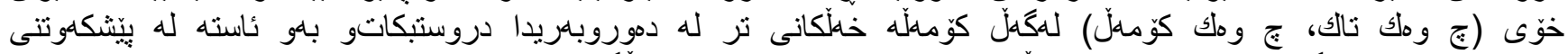

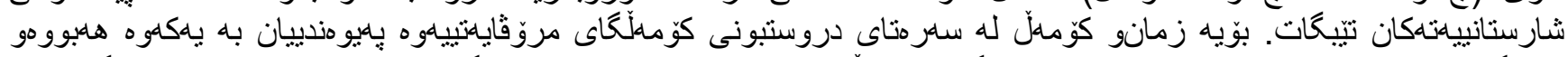

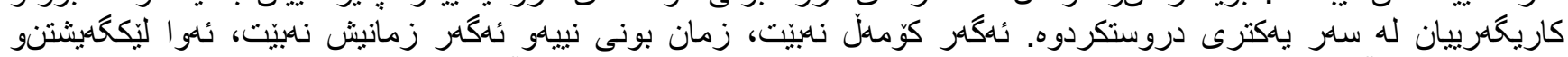

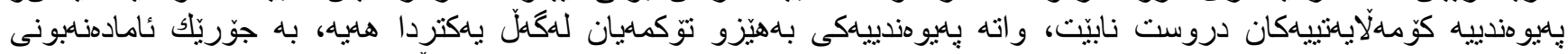

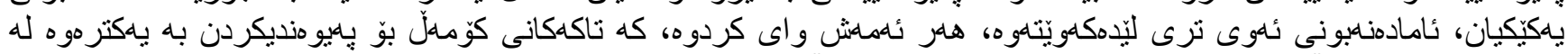

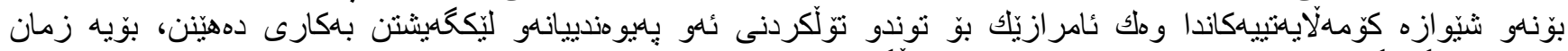

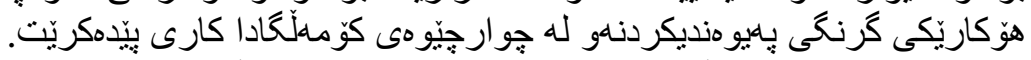

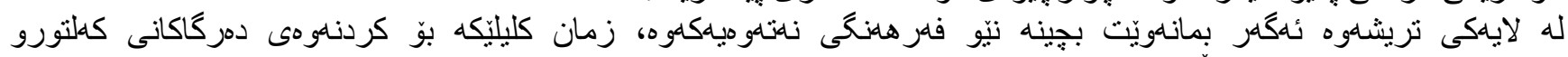

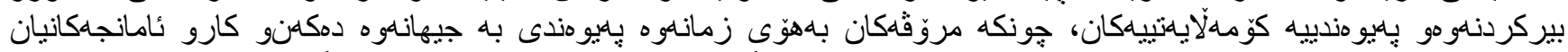

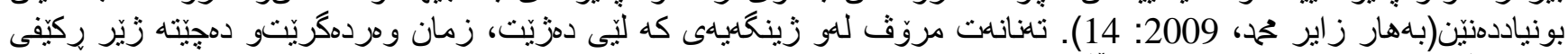

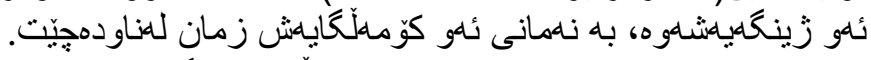

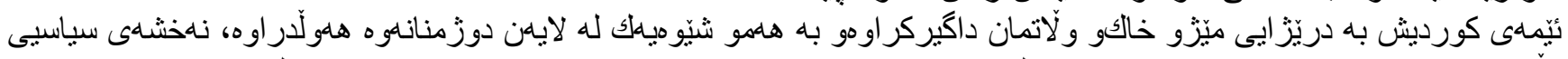



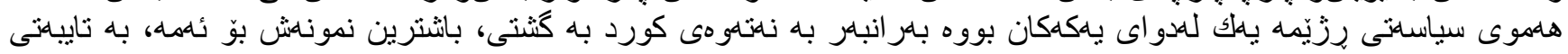

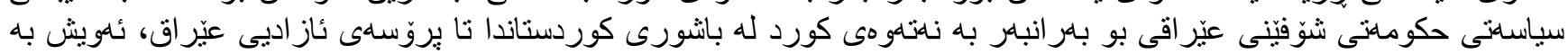

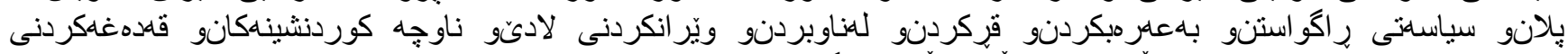

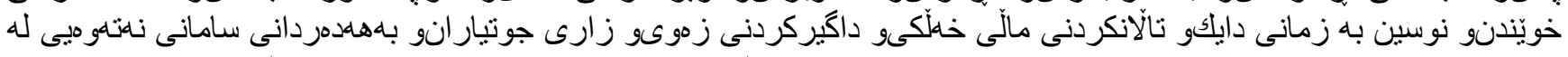

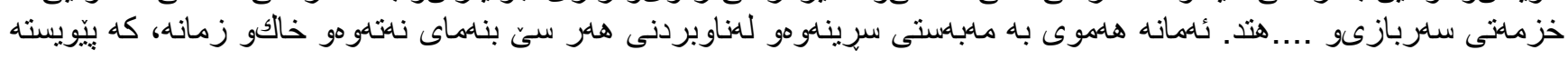




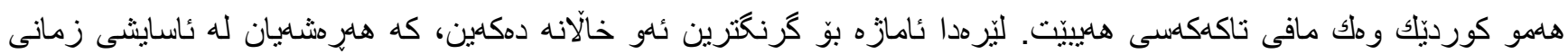

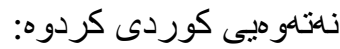
1

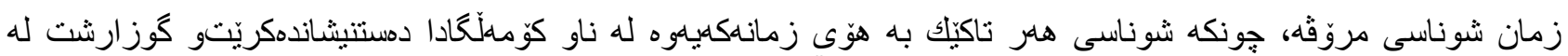

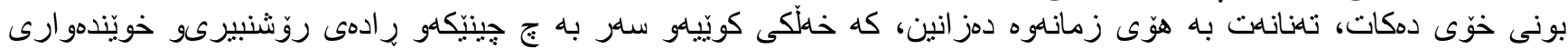

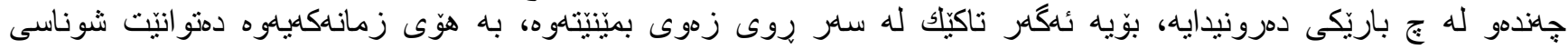

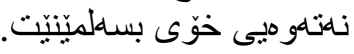

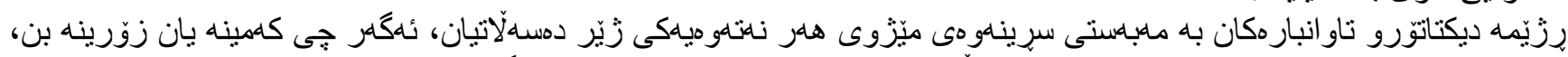

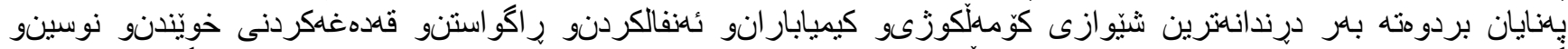

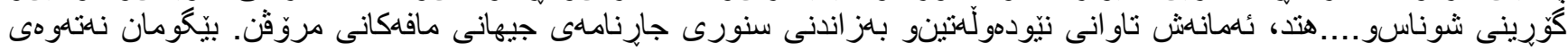

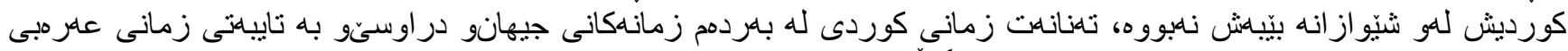

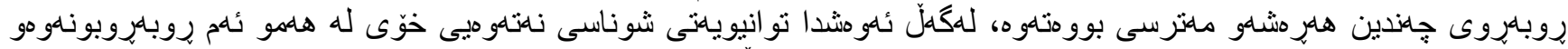

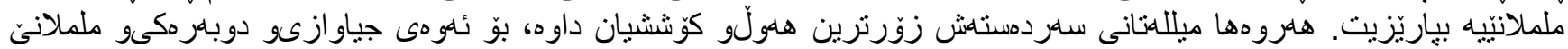

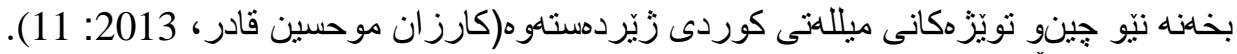

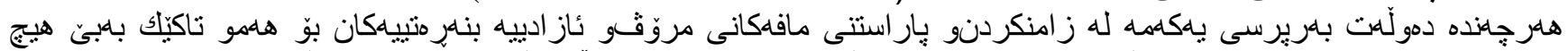

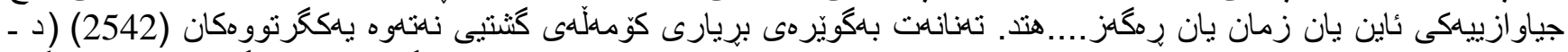



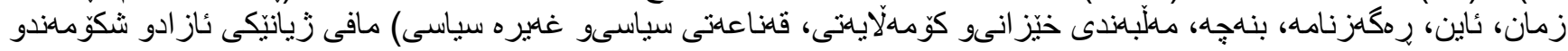

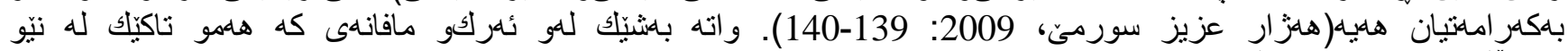

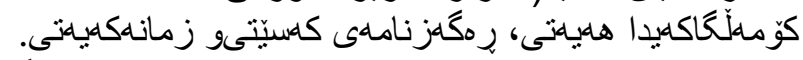

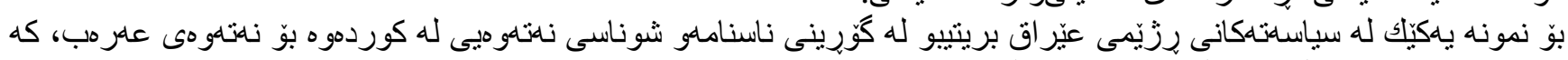

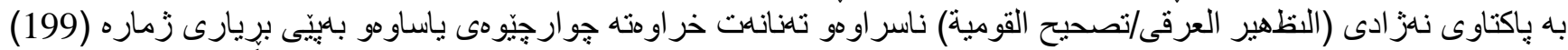



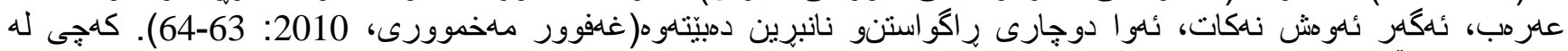

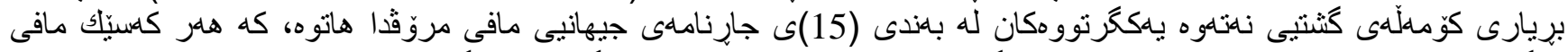

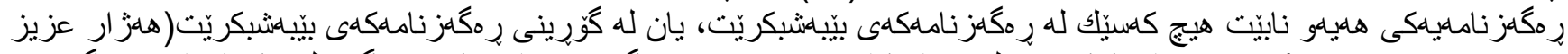

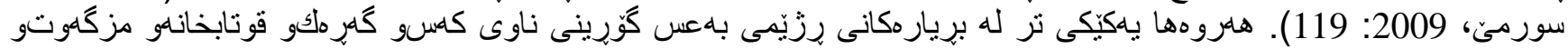

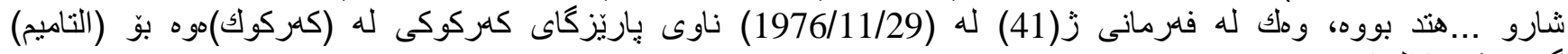

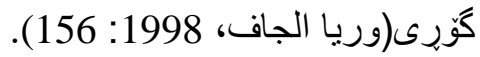
2 - قلهدهغكردنى زمانى نوسينو خويّندن :



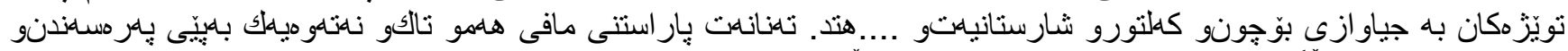

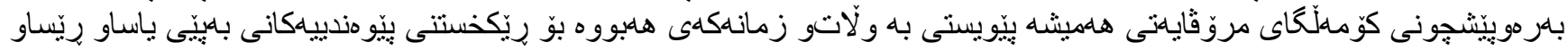

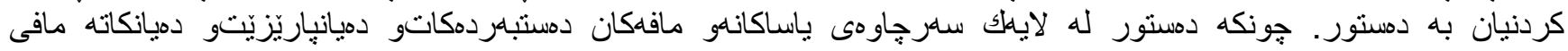

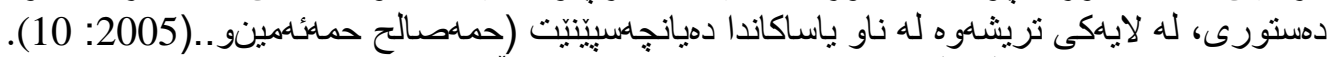

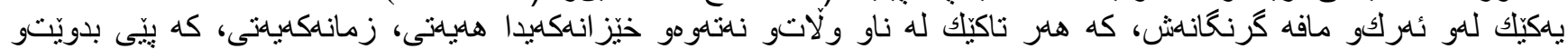

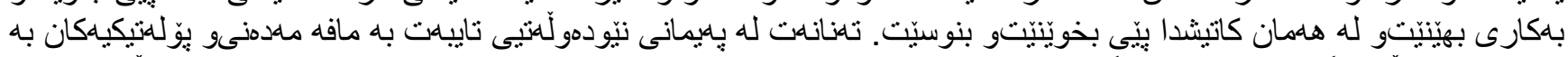

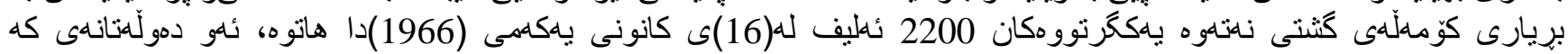

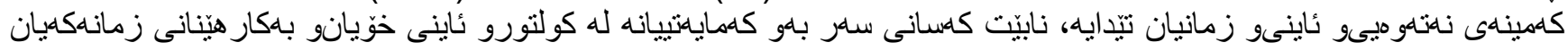

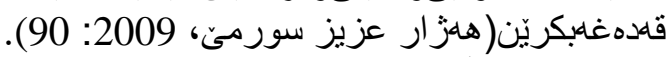



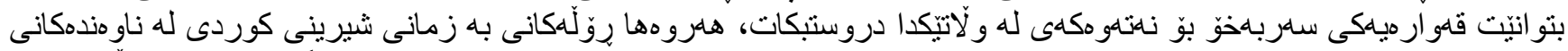

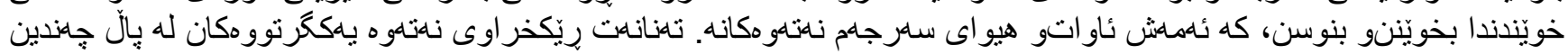

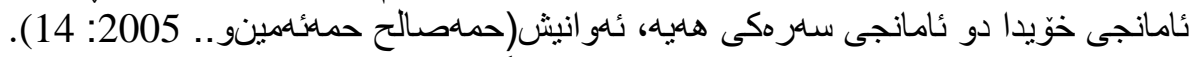

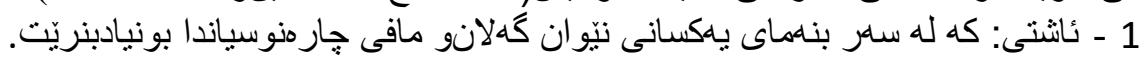

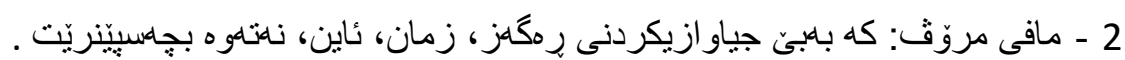






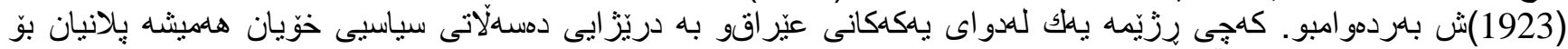

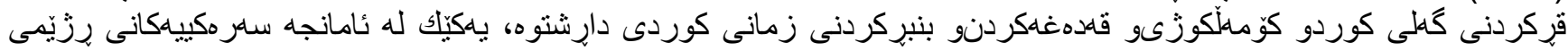

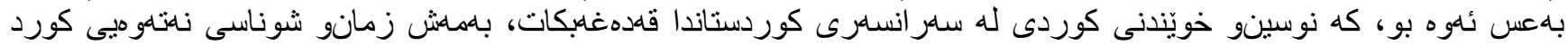

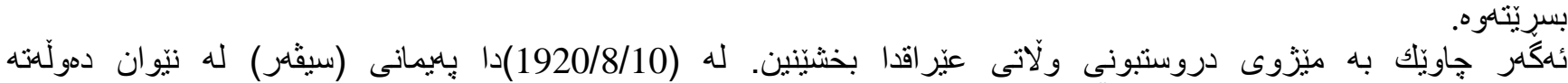

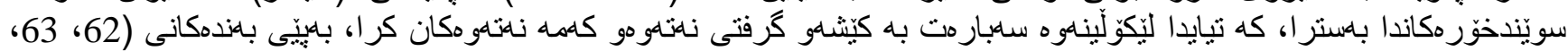

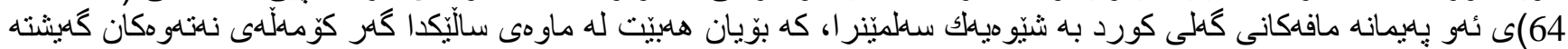

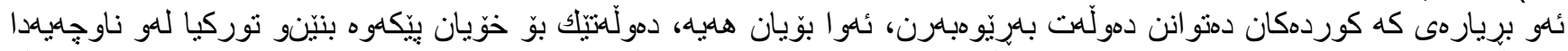

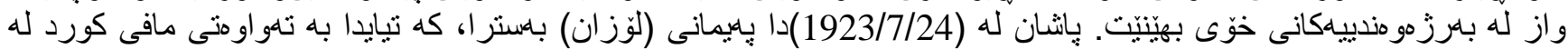

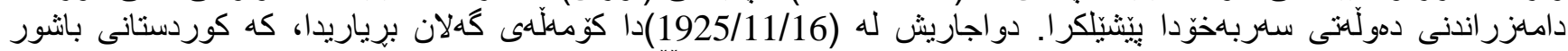

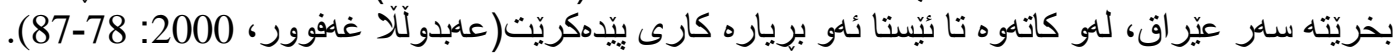

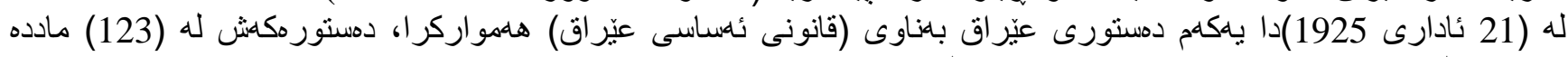

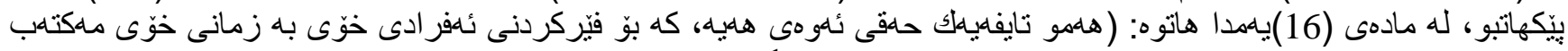

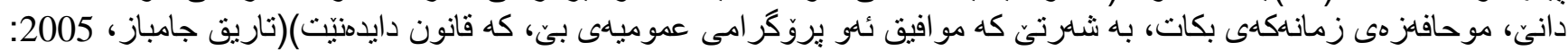

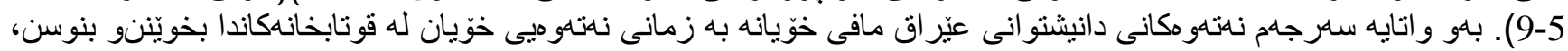

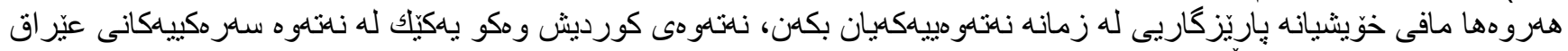

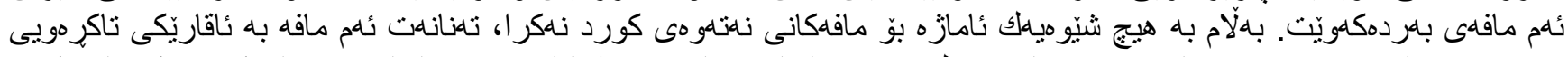

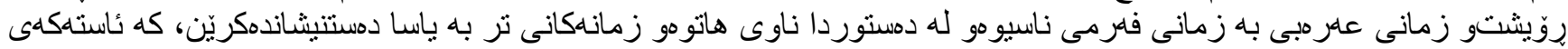
له دوستور نزمتره.



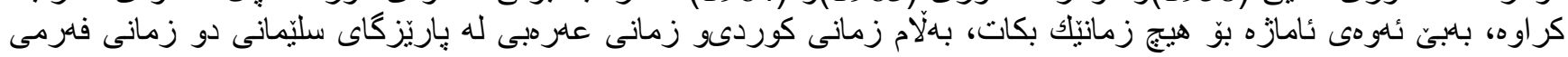

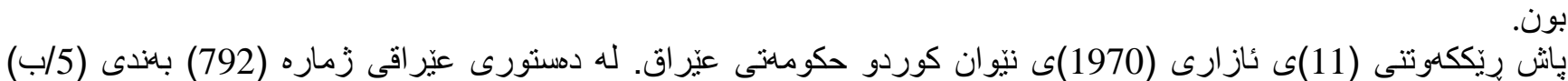

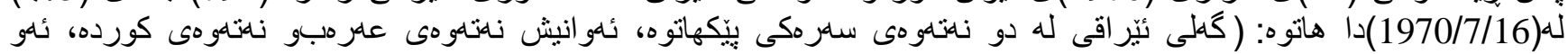

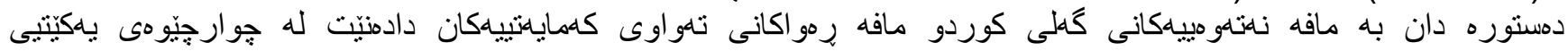

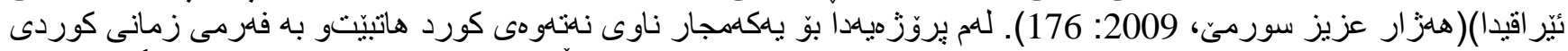

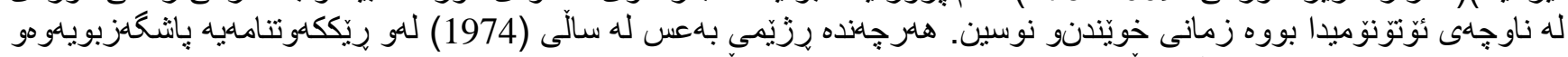

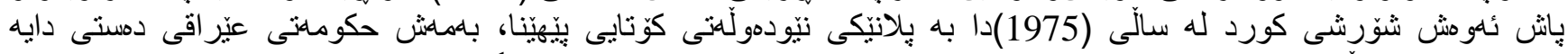

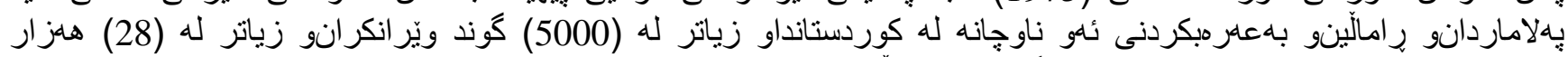

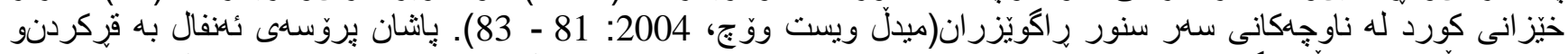

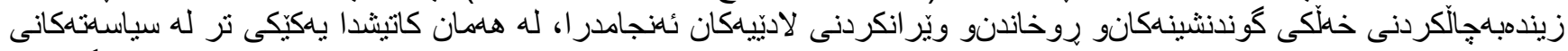

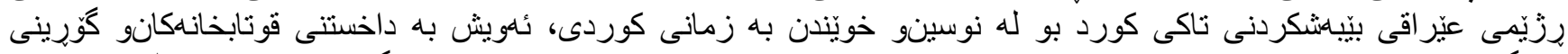

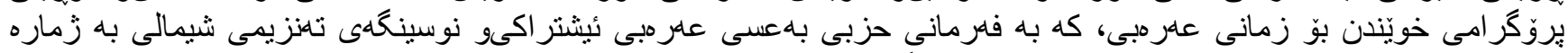

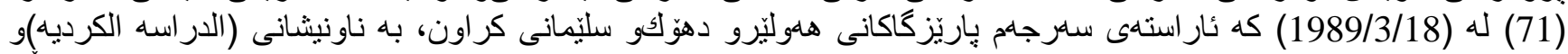



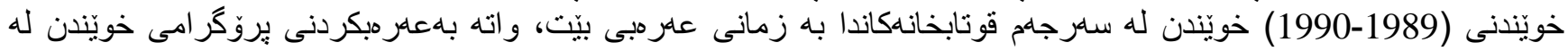



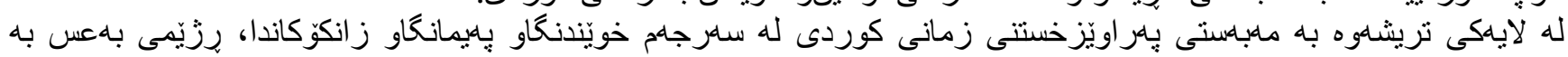

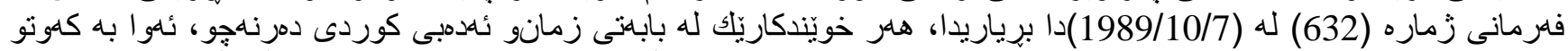

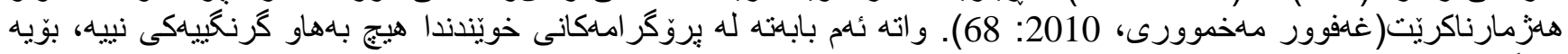

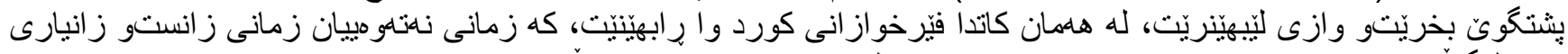

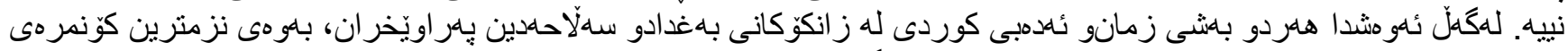

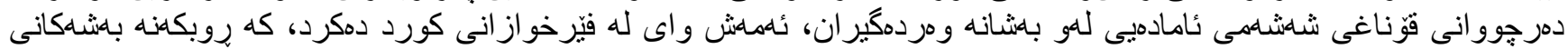

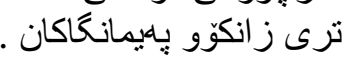

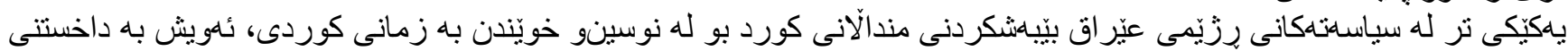

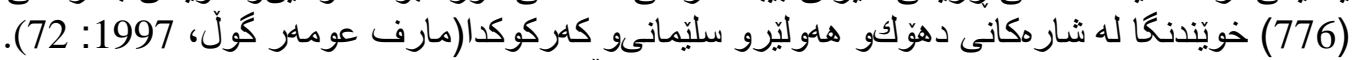

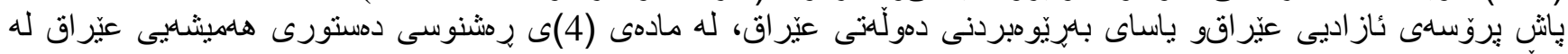

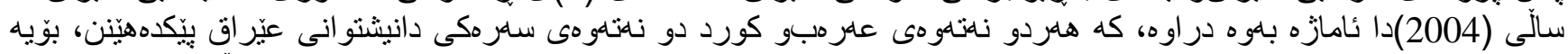






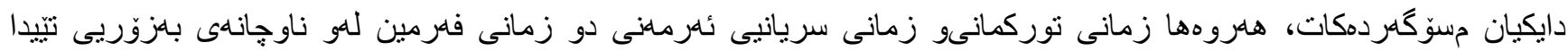



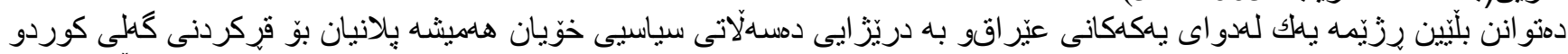

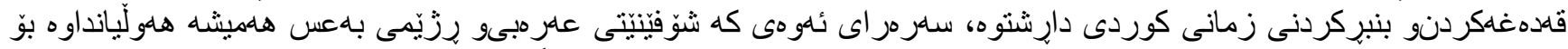

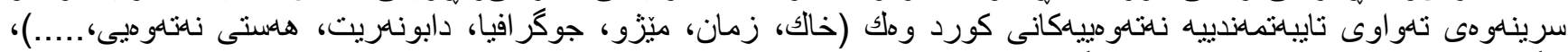

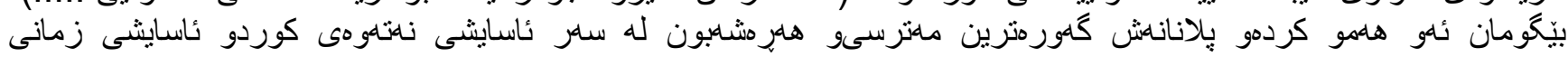
3 - ريراكو استنو بهعلر مبكردن :

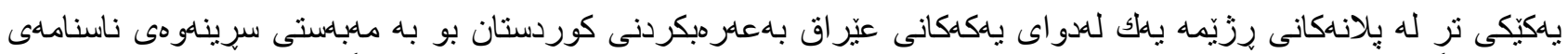

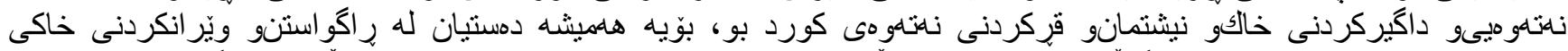



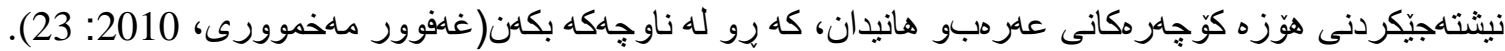

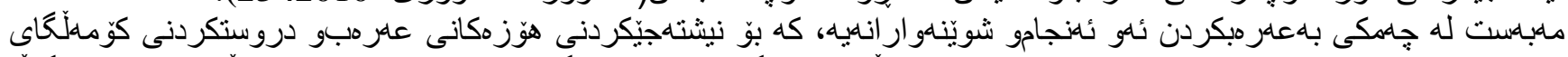

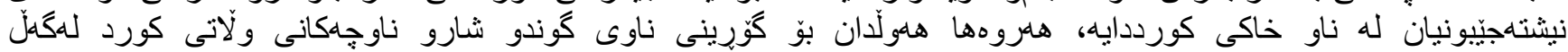

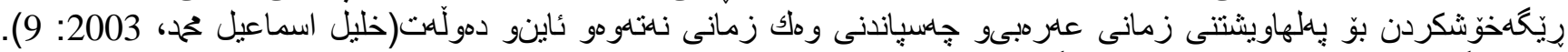



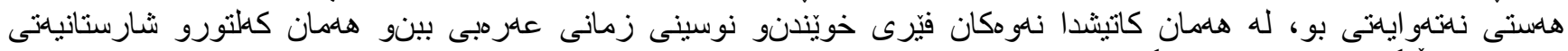

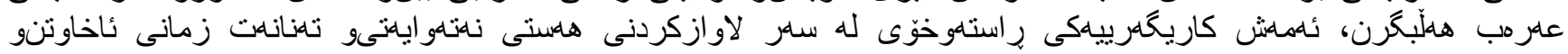

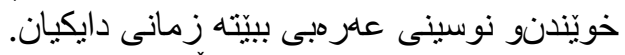



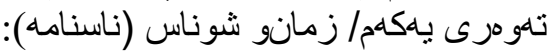

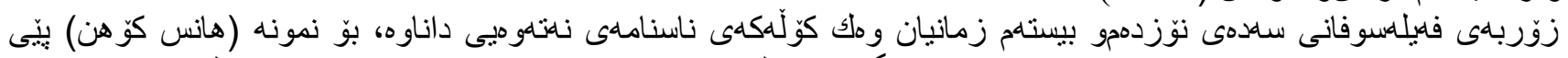

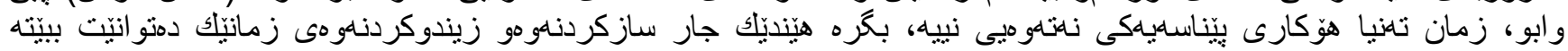



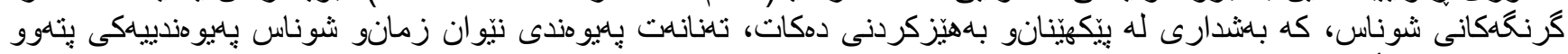

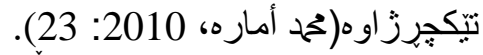

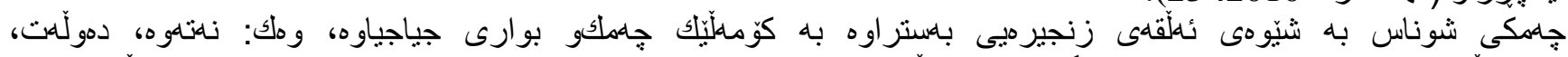

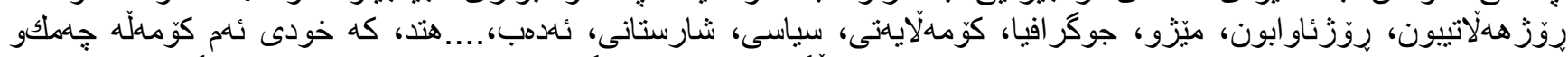

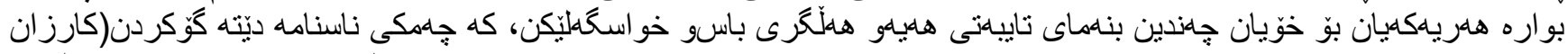

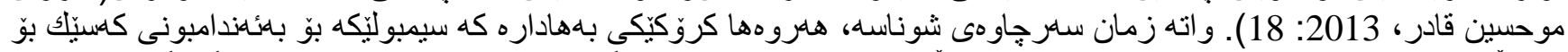

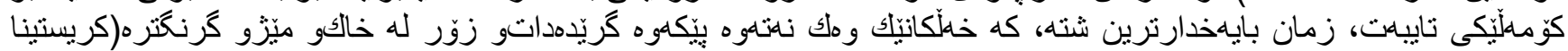

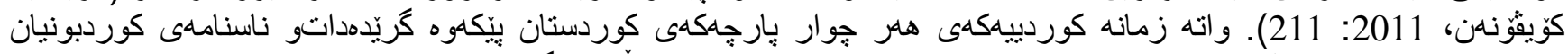

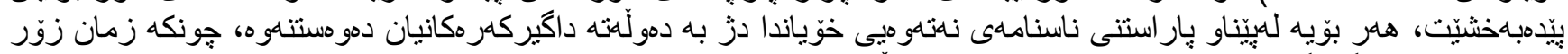

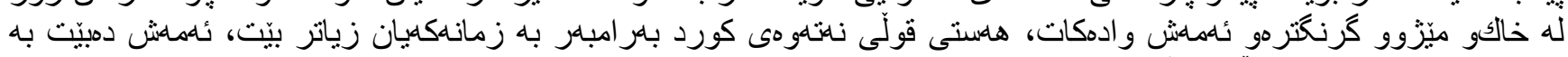

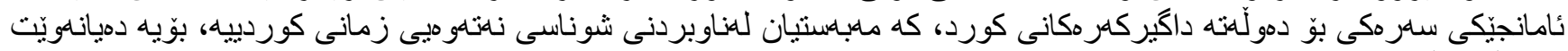



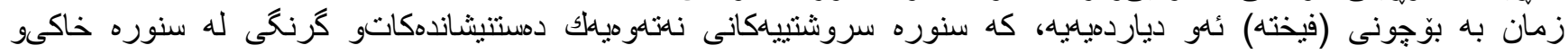

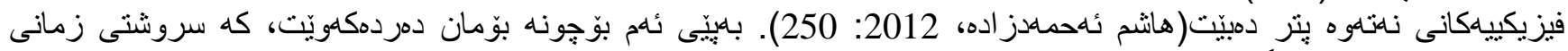

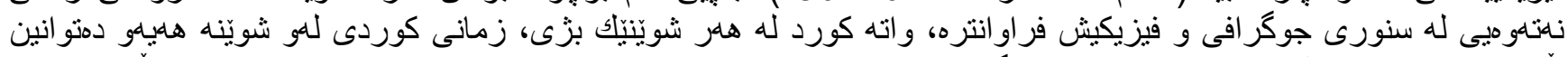

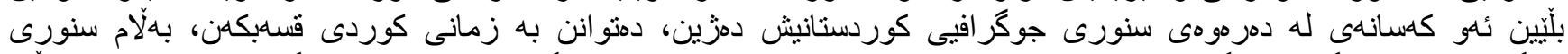

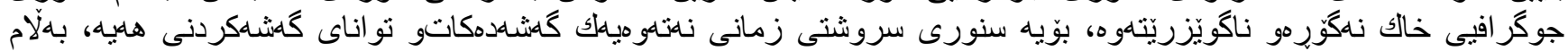

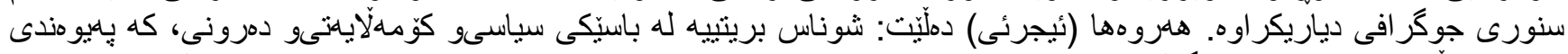

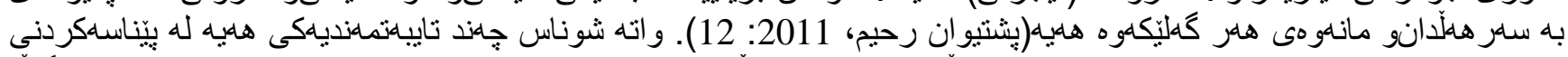

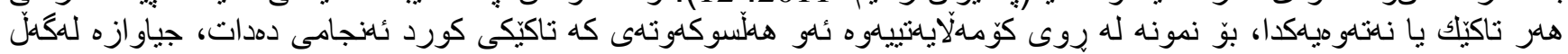


بينّاسهدمكريّت.

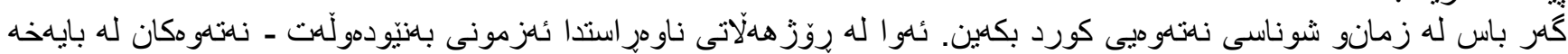



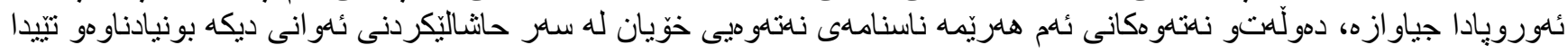




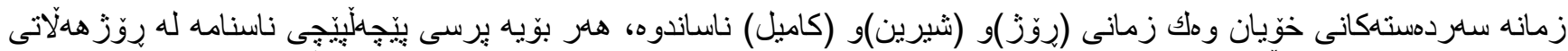

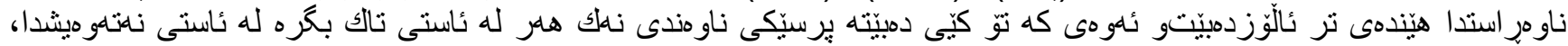





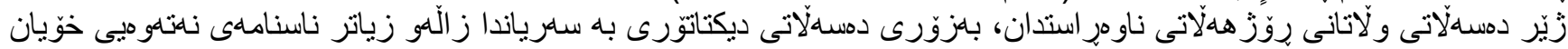



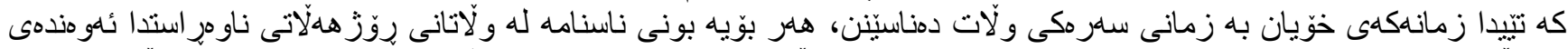

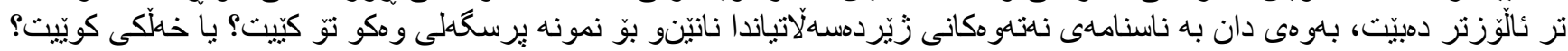

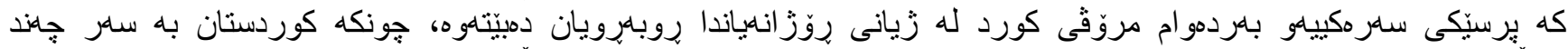

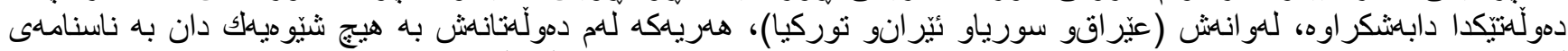



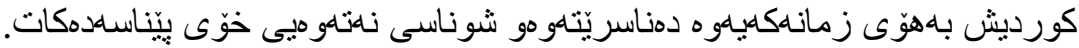

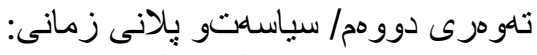

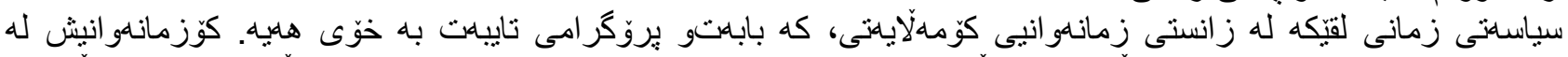

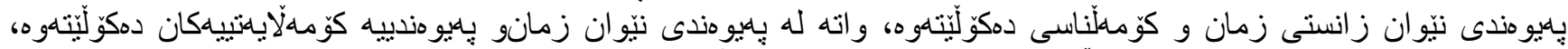

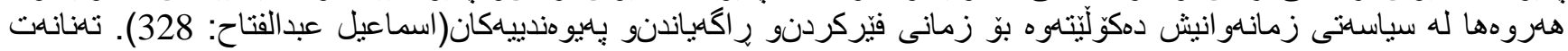

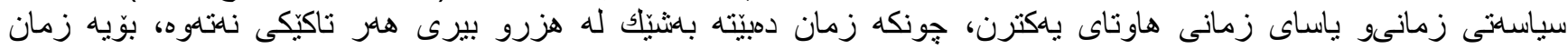

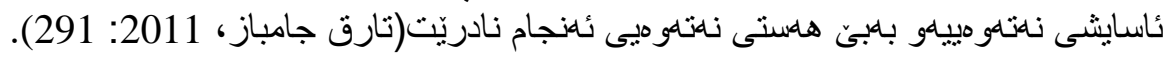

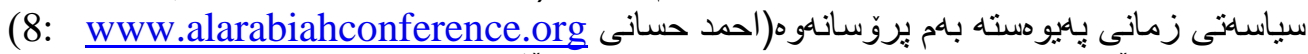

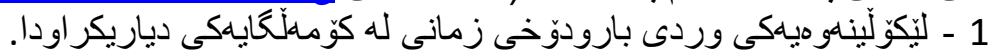

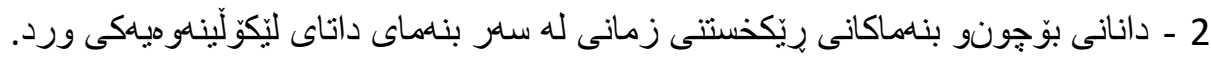

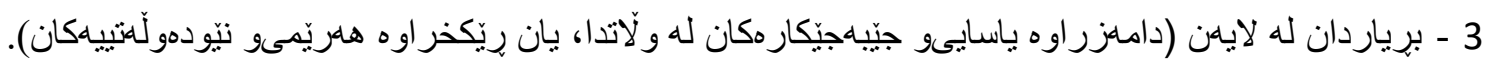

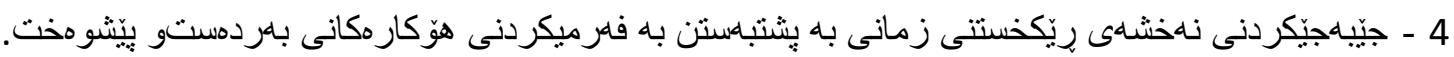

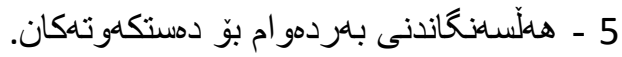

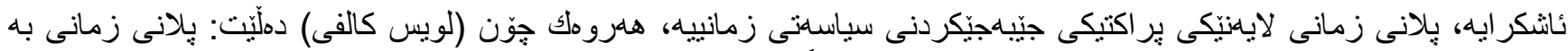

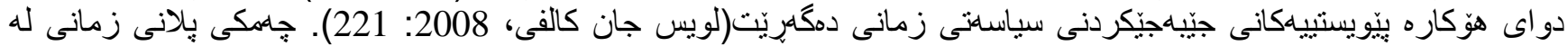



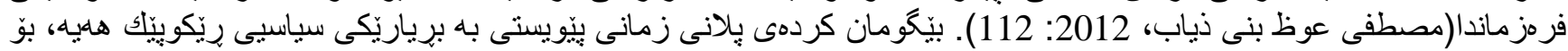

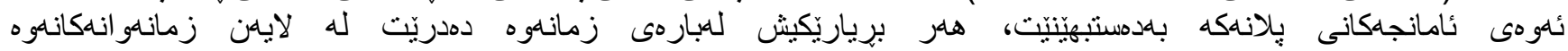

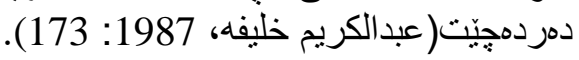

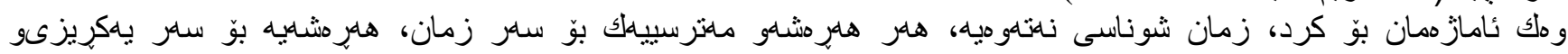

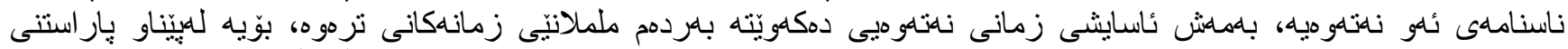

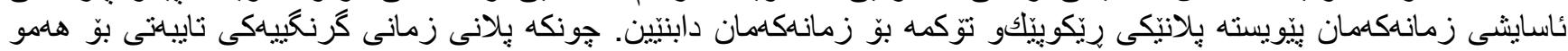

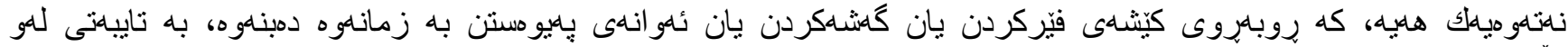

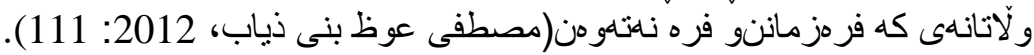

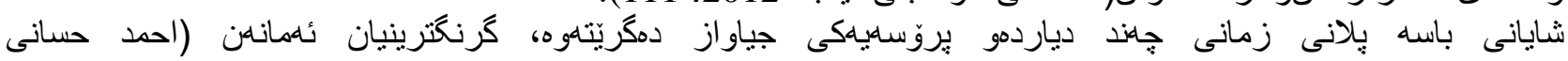
:(8-7:www.alarabiahconference.org:

$$
2 \text { - جاكسازى زمانىى. }
$$

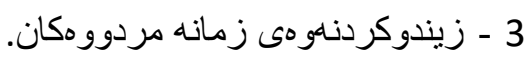

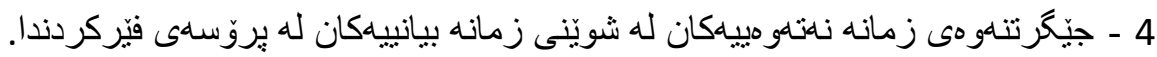

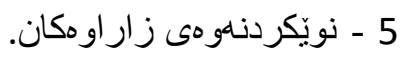

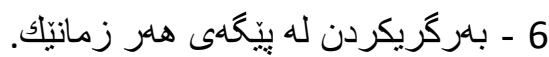

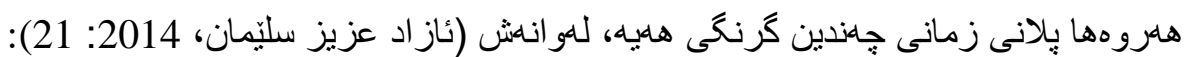



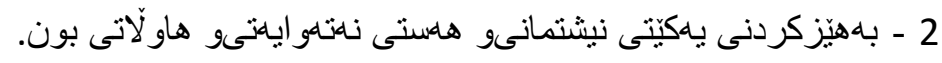




$$
\begin{aligned}
& 3 \text { - بارِيْو هبردنى فرهزمانىو به ستانداركردنى زمانيّاك. }
\end{aligned}
$$

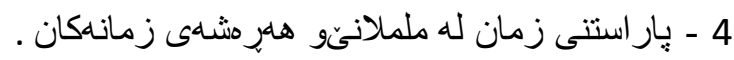

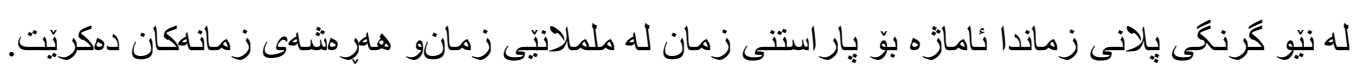

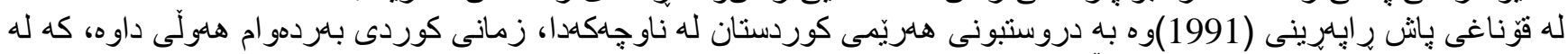

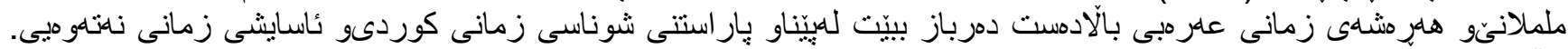

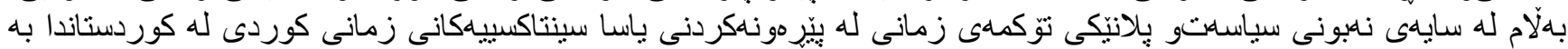

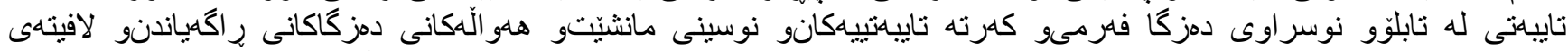

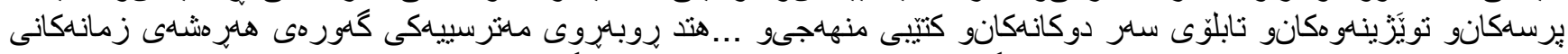

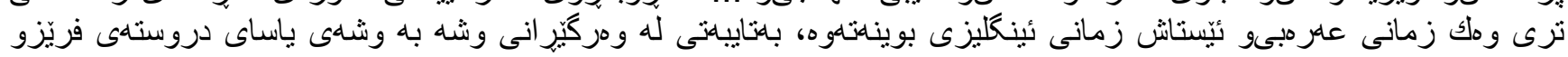
ربتهكاندا.

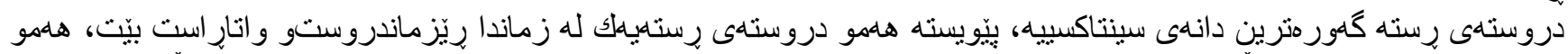

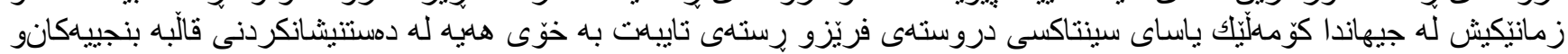

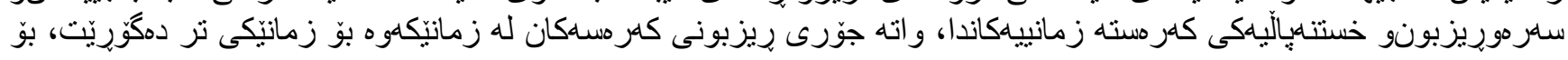

$$
\begin{aligned}
& 1 \text { - كور مكه سيّو هكهى خوارد (بكهر + باكركار + كردار). }
\end{aligned}
$$

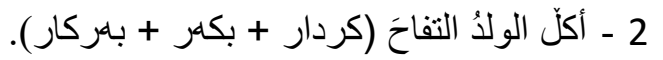

) 3- The boy is eating the apple (

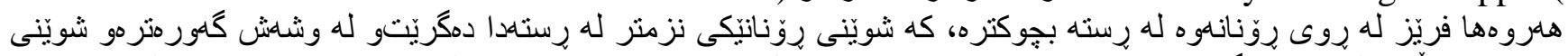

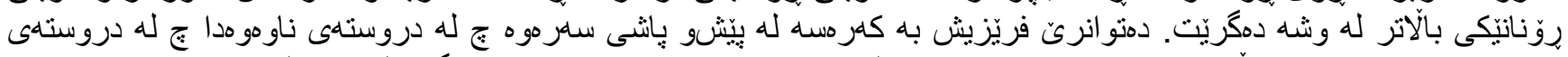

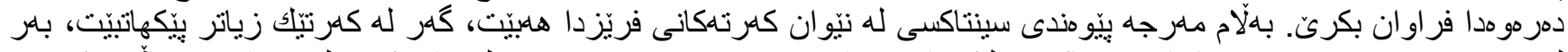

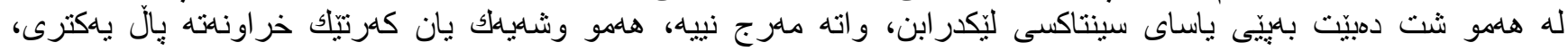

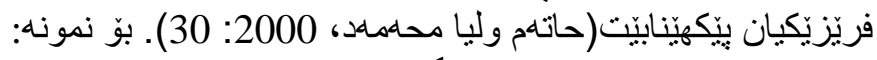

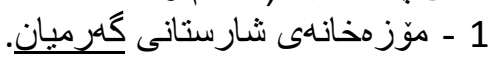
2 - متحف كرميان الحضاري.

3- Garmian civilization museum.

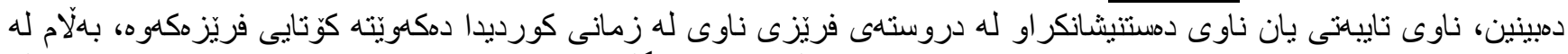

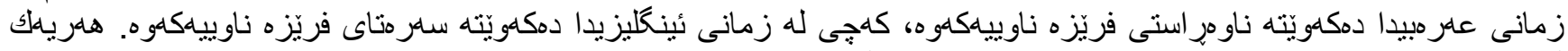

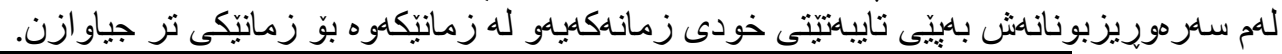



ويَّنهى (1)

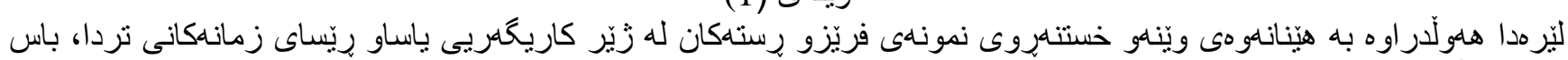

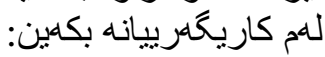

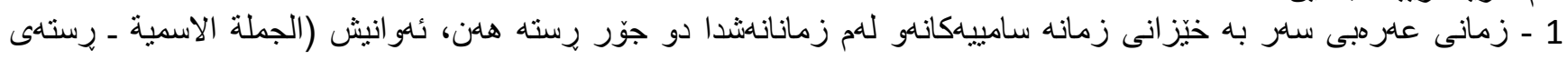



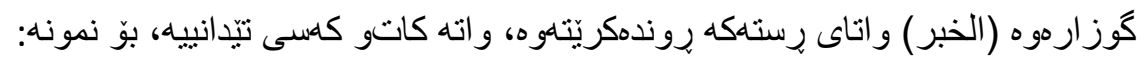




\section{الطالبّ ذكئ / الطالبهُ ذكيةٌ}

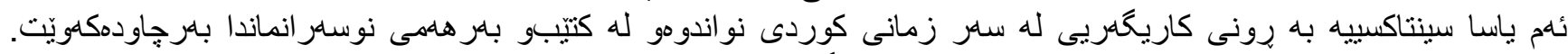



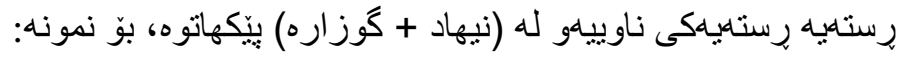



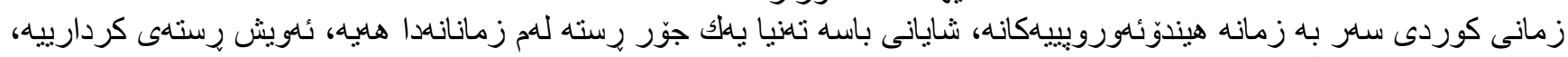

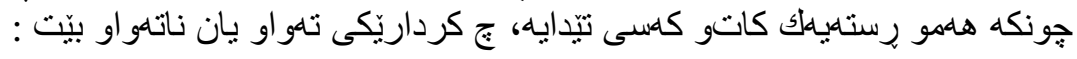

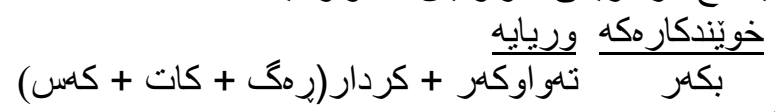



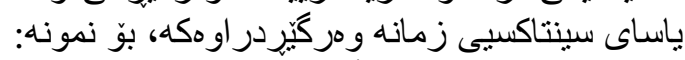
بأقامة ندوة شعرية للسيد.

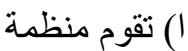

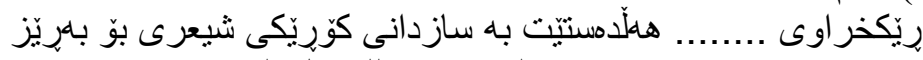

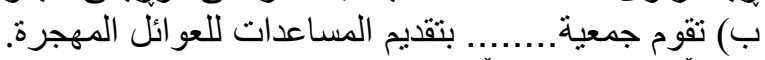

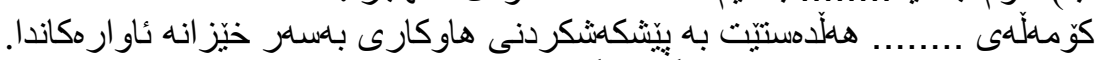

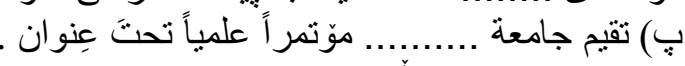



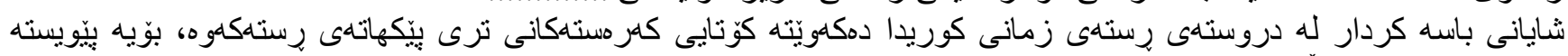

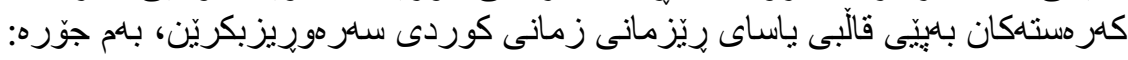



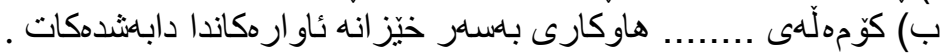

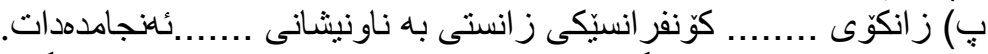

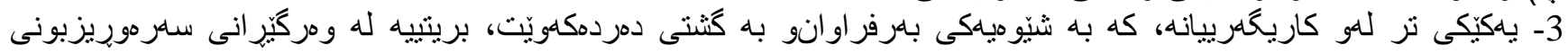

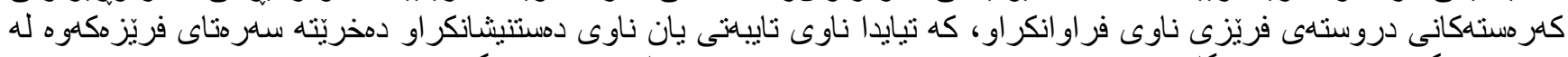



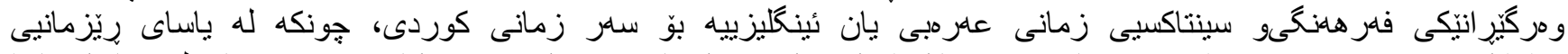

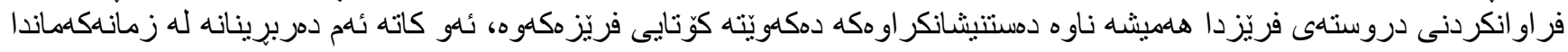

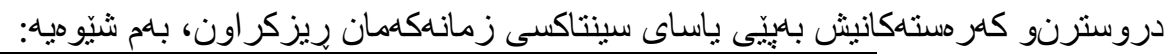



وَيَنهى (2)

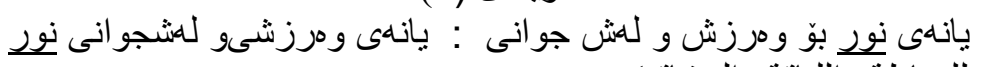

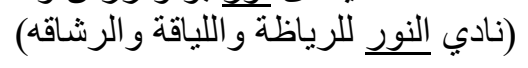






ويَّنهى (3)

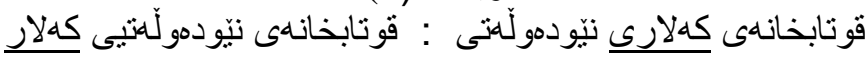
(مدرسة كلار الدولي)

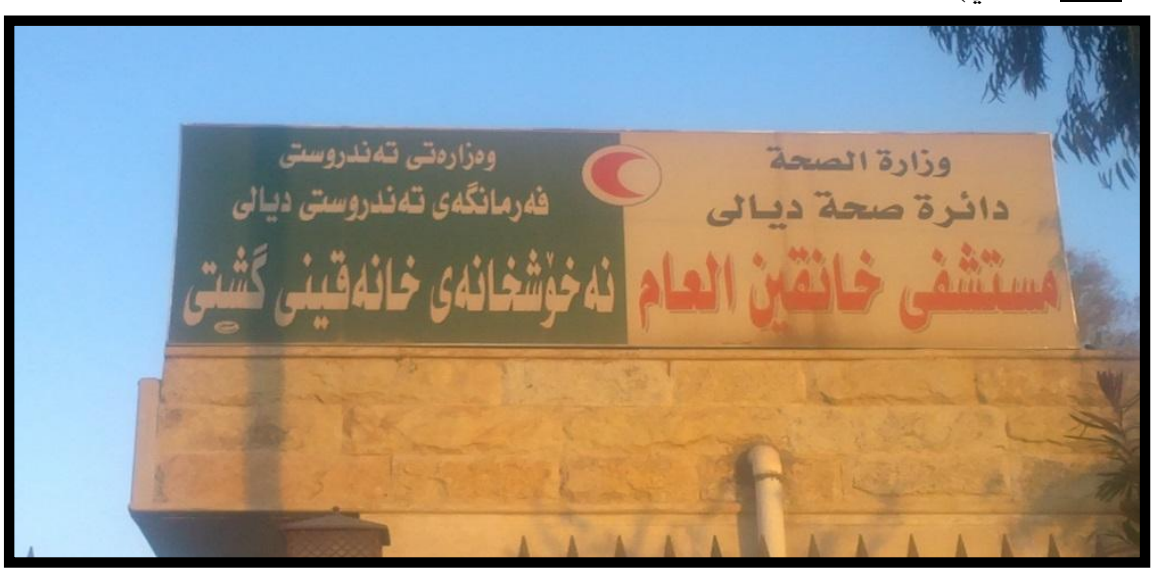

ويَّنهى (4)


(مستشفى خانقين العام)

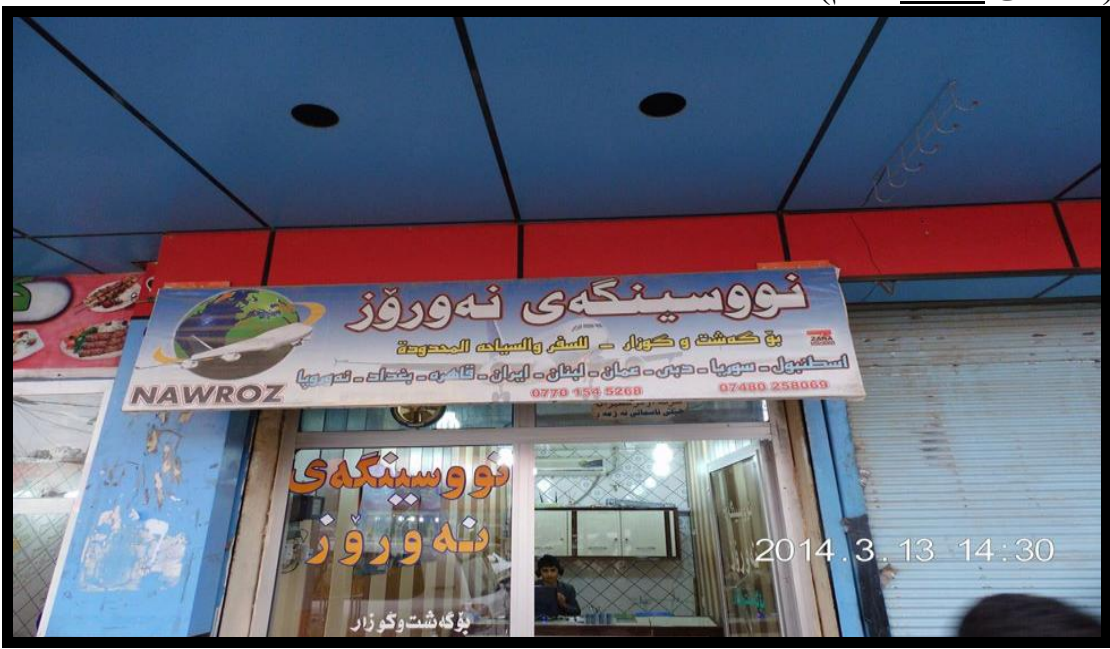

ويَنْهى (5)

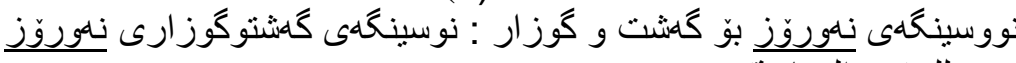

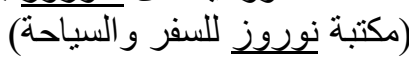




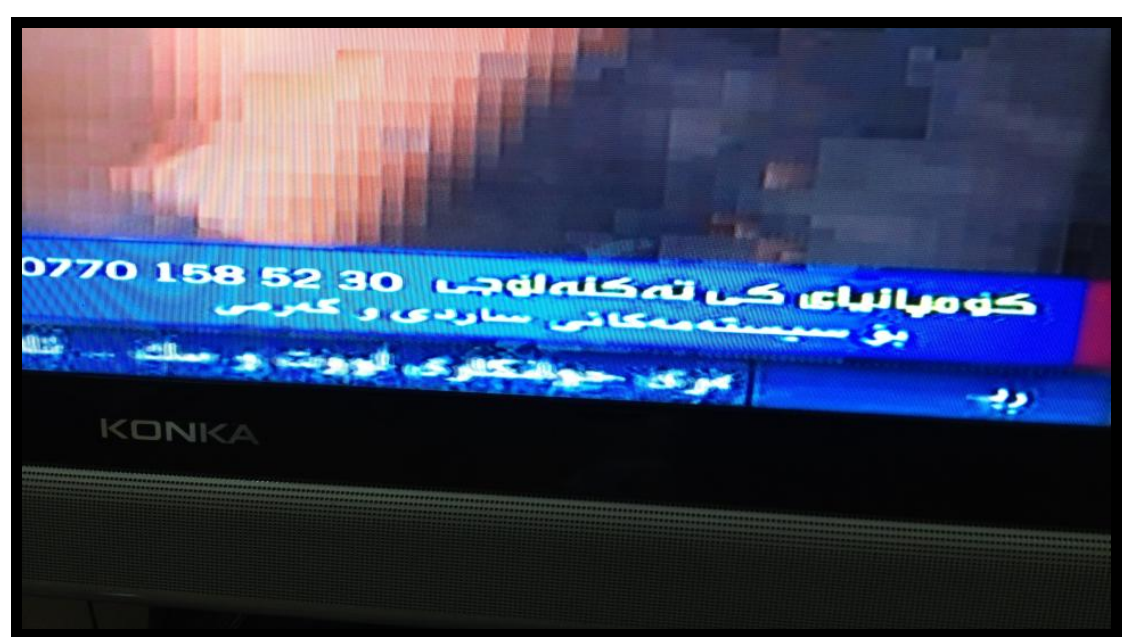

ويَنْهى (6)



$$
\begin{aligned}
& \text { (شركة كي التكنولوجية) }
\end{aligned}
$$

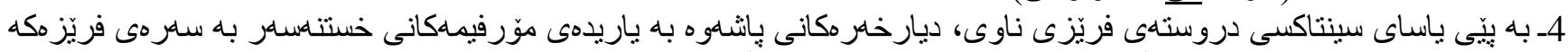

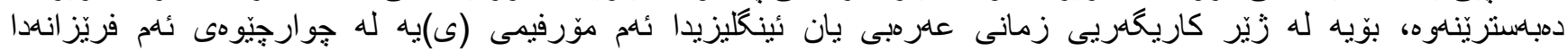

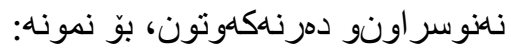
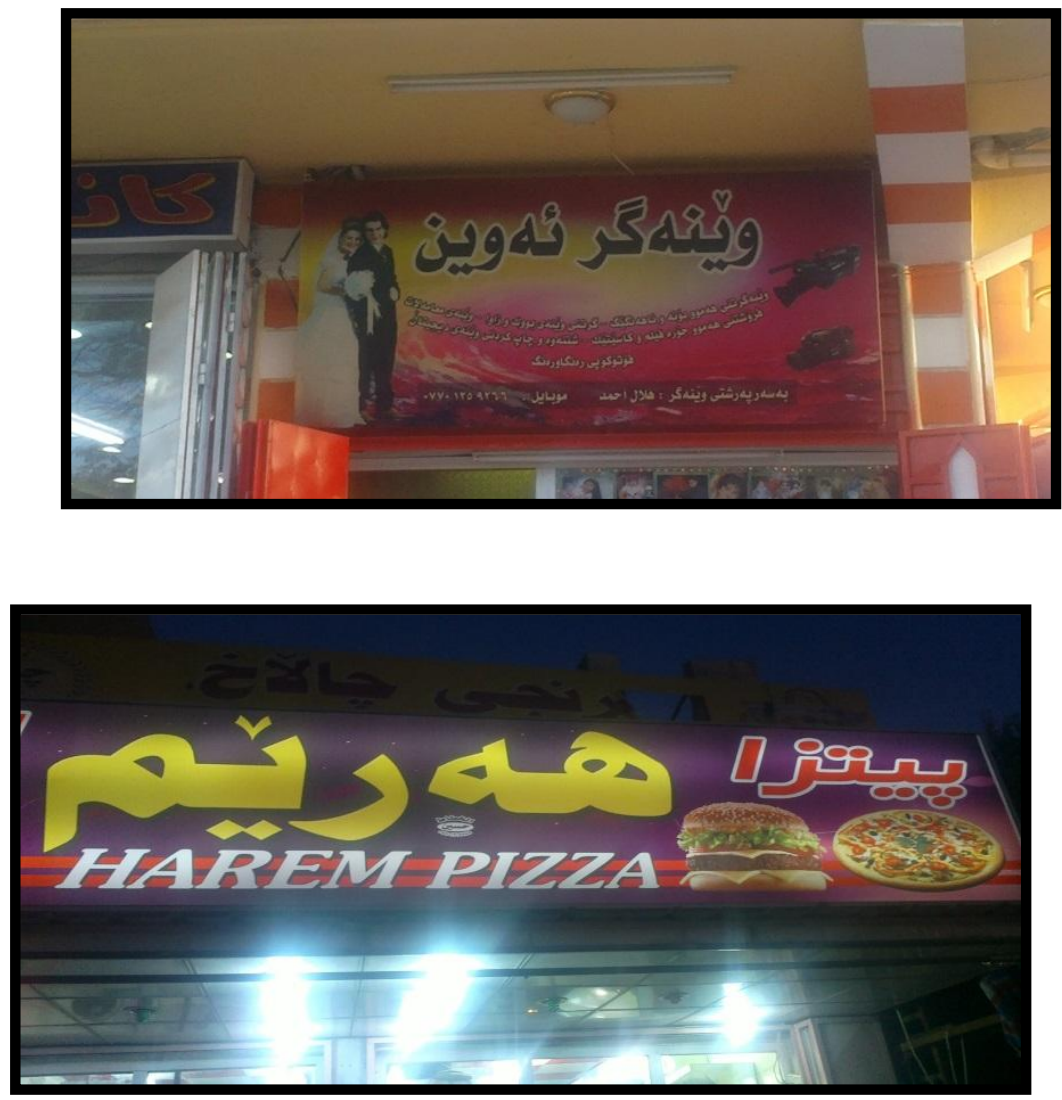

ويَنهى (8)

بيتزز ا هلريّم (Harem pizza) : بينتز اي هليَّم 


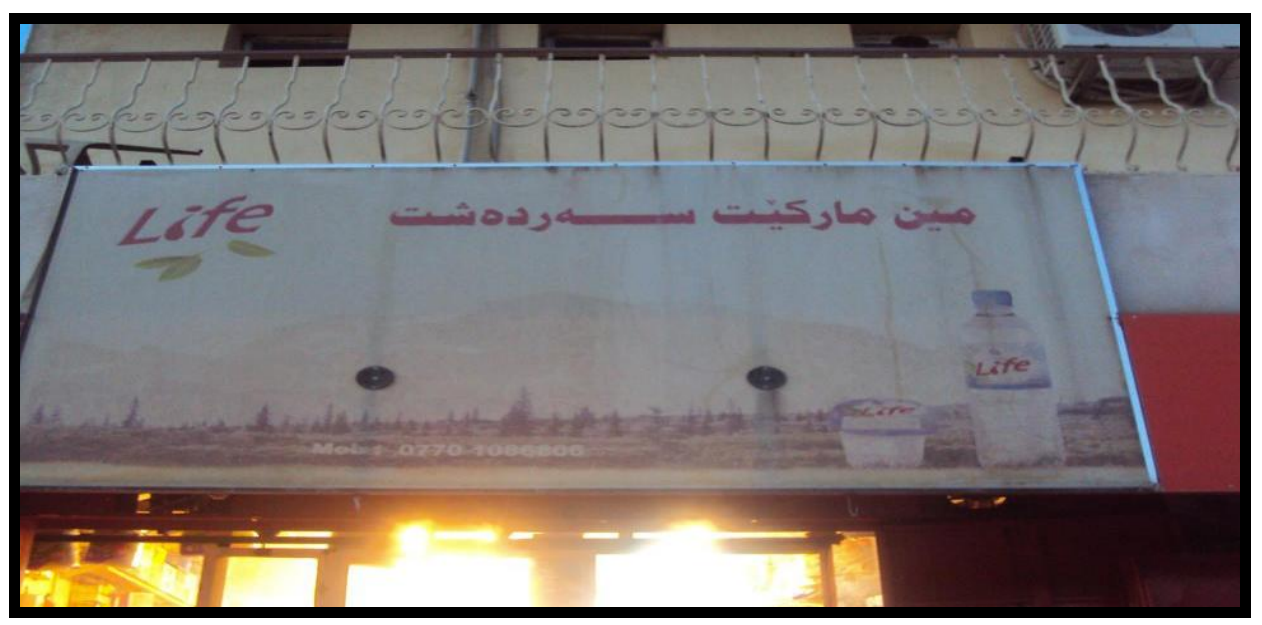

ويَنْى (9)

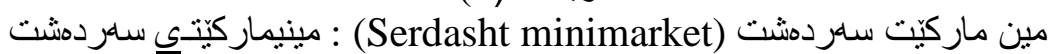

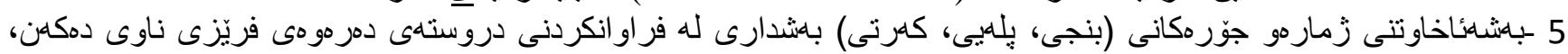

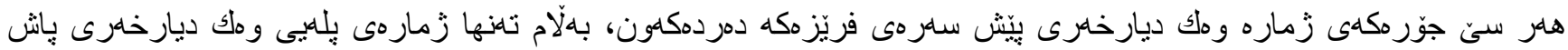

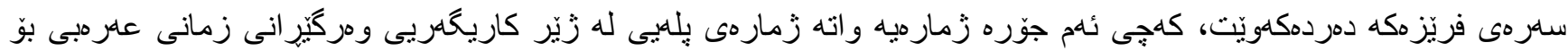

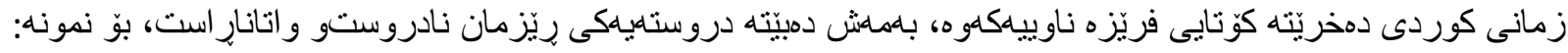

First World War:

Second World War:



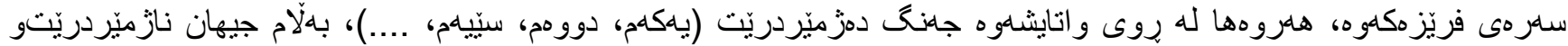



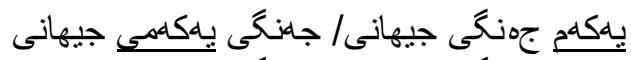

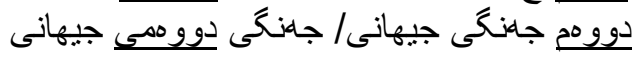

بنوسريّن:

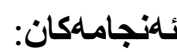

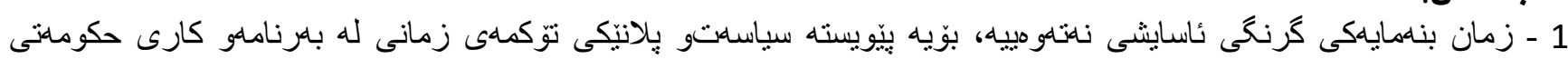

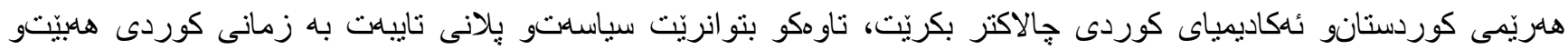

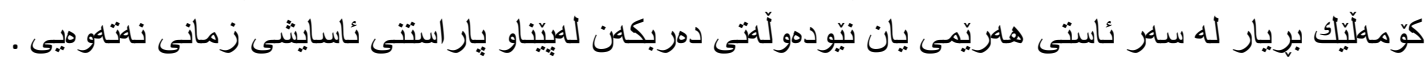

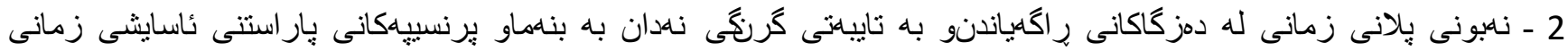

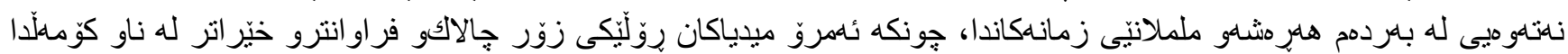

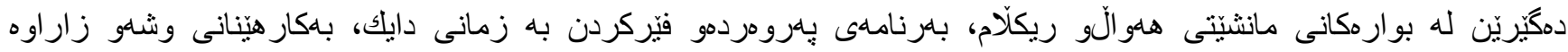

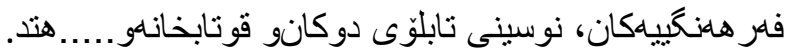



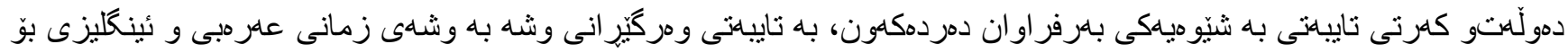

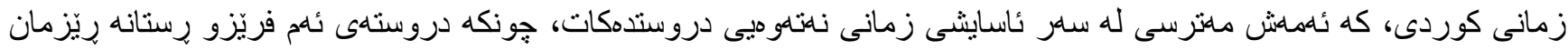

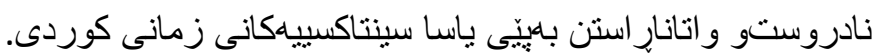

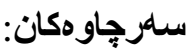

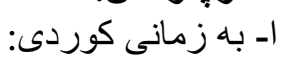

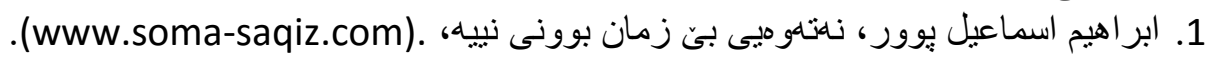

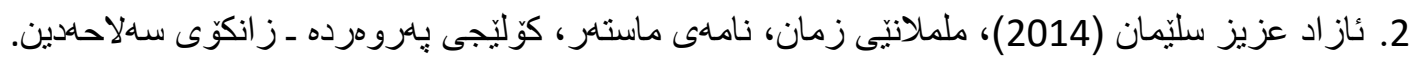

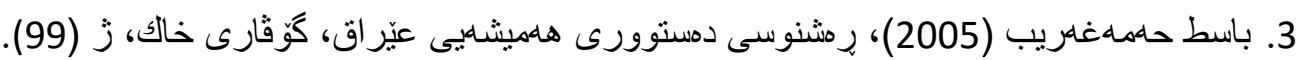






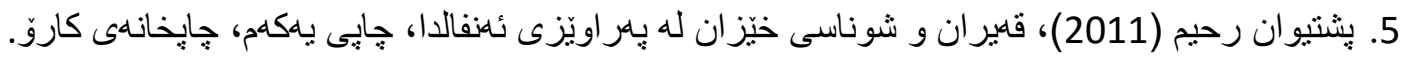

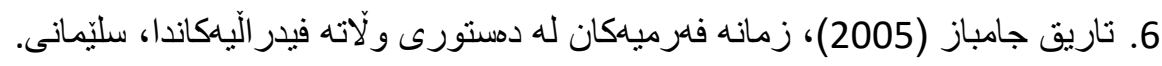

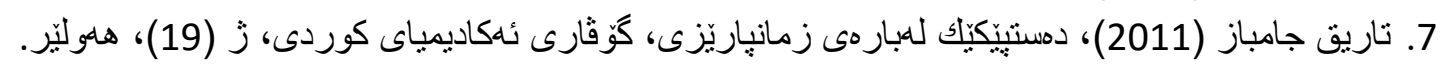

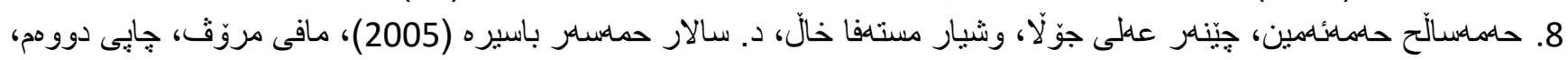

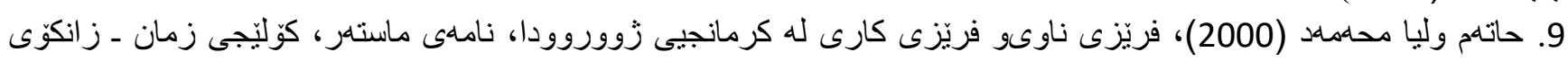
جايخانهى (المثالية).

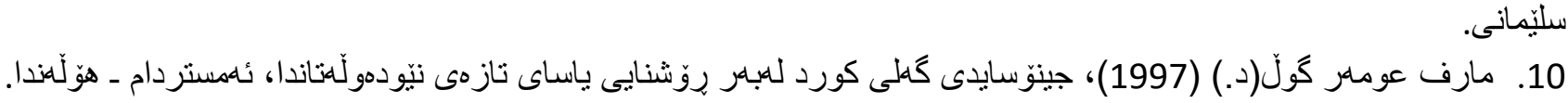

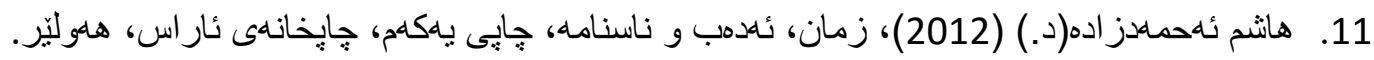



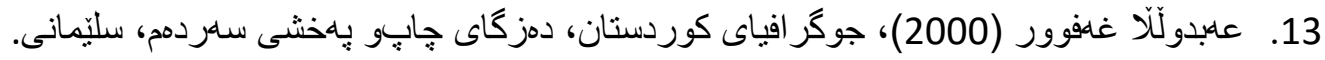

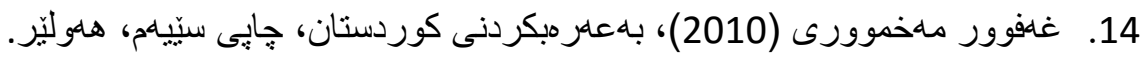




يهارو هرده ـ ز انكوّى كوّيه.

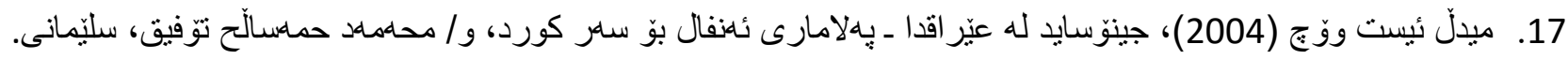

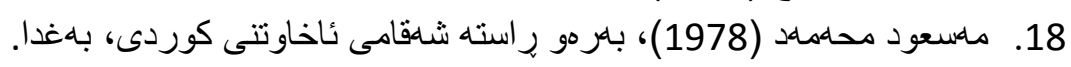

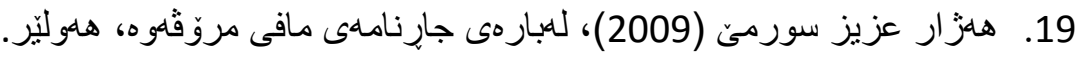

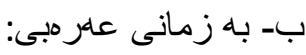

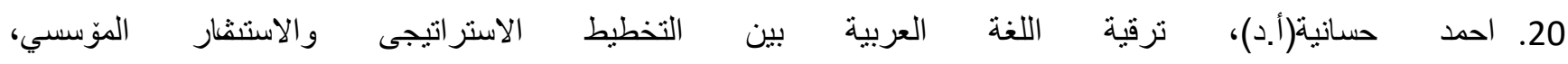
(www.alarabiahconference.org). 21. اسماعيل عبدالفتاح(د.)، معجم مصطلحات عصر العولمة، دار الكتب العربية.

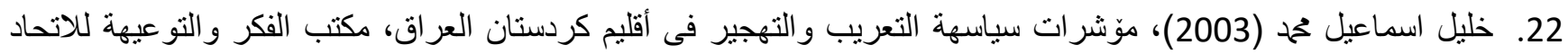
الوطني الكردستانى، السليمانية.



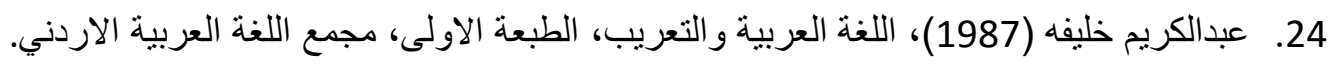

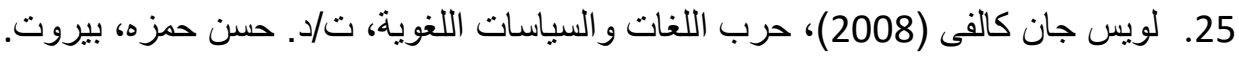


27. مصطفى عوض بنى ذياب(د.) (2012)، التخطيط اللغوى والتعريب، مجلة التعريب، العدد الثاني والاربعون، رجب/حزيران، 28. وريا الجاف (1998)، كركوك دراست سياسية والاجتماعية، أربيل. 